\title{
Toxoplasma gondii antibodies sheep in Lages, Santa Catarina, Brazil, and comparison using IFA and ELISA
}

\author{
Anticorpos toxoplásmicos em ovinos de Lages, Santa Catarina, Brasil, e comparação utilizando RIFI e ELISA
}

Francine Bragagnolo Liz Stefen Sakata ${ }^{1 *}$; Valdomiro Bellato ${ }^{1}$; Amélia Aparecida Sartor ${ }^{1}$; Anderson Barbosa de Moura ${ }^{1}$; Antonio Pereira de Souza ${ }^{1}$; Juliana Antunes Farias ${ }^{1}$

${ }^{1}$ Laboratório de Parasitologia e Doenças Parasitárias, Departamento de Medicina Veterinária, Centro de Ciências Agroveterinárias,
Universidade do Estado de Santa Catarina - UDESC, Lages, SC, Brasil

Received May 31, 2011

Accepted June 18, 2012

\begin{abstract}
Toxoplasmosis in sheep is a disease of great importance in veterinary medicine, which causes economic losses in livestock and has a great impact on human health, since consumption of infected meat facilitates transmission of zoonotic infections. Blood samples from sheep $(n=360)$ were collected from 13 farm properties in the municipality of Lages, Santa Catarina, to estimate the prevalence of toxoplasmosis and identify risk factors associated with Toxoplasma gondii infection. T. gondii, antibodies were investigated by means of the indirect immunofluorescence assay (IFA) and enzyme-linked immunosorbent assay (ELISA). Animals infected with T. gondii were found on $100 \%$ of the farms. IFA detected $56.9 \%(205 / 360)$ and ELISA $42.5 \%$ of the infected sheep. Breed was the only risk factor associated with the presence of $T$. gondii antibodies. ELISA showed sensitivity of $61 \%$, specificity of $82 \%$ and kappa of 0.41 , which was considered moderate. This allows use of ELISA as an alternative technique for diagnosing T. gondii in sheep.
\end{abstract}

Keywords: Toxoplasma gondii, sheep, IFA, ELISA, risk factors.

\section{Resumo}

A toxoplasmose ovina é uma doença parasitária de elevada importância em medicina veterinária e em saúde pública, acarretando prejuízos na produção animal, gerados pelas perdas reprodutivas e econômicas, além de sua implicação na saúde humana, já que o consumo de carne infectada facilita a transmissão zoonótica. Para determinar a prevalência e identificar fatores de risco para a infecção por T. gondii em ovinos de Lages, Santa Catarina, amostras de sangue $(\mathrm{n}=360)$ foram coletadas em 13 propriedades. Cada criador respondeu a um questionário para permitir a identificação dos fatores de risco da infecção. A pesquisa de anticorpos foi realizada por meio da Reação de Imunofluorescência Indireta (RIFI $\geq 64$ ) e do Ensaio Imunoenzimático Indireto (ELISA). Em 100\% das propriedades foram encontrados animais positivos. Pela RIFI, 205 (56,94\%) ovinos apresentaram anticorpos contra T. gondii e pelo ELISA, 153 (42,50\%). Considerando-se as técnicas sorológicas e a análise estatística, foram fatores de risco pelo ELISA: a idade, a fonte de água e a categoria animal; e pela RIFI, o tipo racial. Foi constatada sensibilidade de $61 \%$, especificidade de $82 \%$ e concordância Kappa de 0,41 entre o ELISA e a RIFI (1:64), considerada moderada, permitindo indicar o ELISA como técnica adequada para o diagnóstico de $T$. gondii na espécie ovina.

Palavras-chave: Toxoplasma gondii, ovinos, RIFI, ELISA, fatores de risco.

\section{Introduction}

Toxoplasmosis is a zoonosis that is usually asymptomatic. It is caused by the coccidian Toxoplasma gondii and has worldwide distribution. Consumption of raw or undercooked meat containing tissue cysts is a major source of infection for carnivores and omnivores, while herbivores are primarily infected by ingestion

\footnotetext{
${ }^{*}$ Corresponding author: Francine Bragagnolo Liz Stefen Sakata

Laboratório de Parasitologia e Doenças Parasitárias, Departamento de Medicina

Veterinária, Centro de Ciências Agroveterinárias, Universidade do Estado de

Santa Catarina - UDESC, Av. Luis de Camóes, 2090,

CEP 88520-000, Lages, SC, Brasil

e-mail: franstefen@yahoo.com.br
}

of oocysts. Another mode of disease transmission is transplacental transmission, which has been blamed for abortions, neonatal mortality and weakness in humans and some animal species, especially small ruminants (DUBEY; THULLIEZ, 1993). The main clinical and economic impact of toxoplasmosis in sheep is abortion, along with losses due to stillbirth or birth of weak lambs (TENTER et al., 2000).

In the state of Santa Catarina, Brazil, sheep herds on the plateau and in the western region account for more than $60 \%$ of this state's population (IBGE, 2009). The municipality of Lages is also prominent because of its sheep population. On this plateau, 
sheep are primarily raised in semi-extensive farming systems, and there is no individual control over breeding on the farm properties. Thus, the rates of pregnancy, abortion and lamb loss are not precisely known. Moreover, little is known about the causes of reproductive disorders and their relationship with $T$. gondii.

The gold standard test, which is used worldwide for final diagnosis of $T$. gondii antibodies in animals, is the immunofluorescence assay (IFA). The enzyme-linked immunosorbent assay (ELISA) is used mainly for detection of antibodies when a simpler, cheaper and faster seroepidemiological survey is necessary. It is known that IFA has greater specificity and that ELISA has greater sensitivity (BRASIL, 2002).

Considering the importance of this infection and the lack of health data relating to the sheep industry in the state of Santa Catarina, the present study was conducted with the aims of estimating the prevalence of $T$. gondii infection among sheep in the municipality of Lages using IFA, and evaluating ELISA as the test for diagnosing toxoplasmosis in sheep and identifying risk factors associated with $T$. gondii infection in these animals.

\section{Materials and Methods}

Between August 2008 and July 2009, blood samples were collected from 360 sheep on 13 farm properties in the municipality of Lages, state of Santa Catarina.

The sheep population of the municipality was estimated to be 10,581 animals (CIDASC, ICASA, 2008). The Epi Info software (version 6, CDC - Center for Disease Control and Prevention, Atlanta, USA) was used to calculate the animal sample size, assuming that the prevalence of toxoplasmosis in sheep would be around $30 \%$, with a $95 \%$ confidence interval (CI) and error of 5\% (CDC, 1996). Blood samples were properly identified, packaged and transported to the Parasitology and Parasitic Disease Laboratory, Agroveterinary Science Center (CAV), University of the State of Santa Catarina (UDESC).

Information on health and management factors that could potentially be considered to pose a risk of $T$. gondii infection was obtained through questionnaires answered by the farm owners on the day of collecting blood samples from the animals. The variables analyzed were age, sex, breed, diet, water source, contact with cats, breeding problems, rearing system and animal category.

IFA for toxoplasmosis was performed using $T$. gondii tachyzoites (RH strain) as antigen. The slides, already spotted with a tachyzoite suspension, were kindly provided by the Protozoology Laboratory, Department of Preventive Veterinary Medicine, Sate University of Londrina (UEL). Examinations were performed in accordance with the methods described by Camargo (1964) and Paré et al. (1995).

Samples with a reaction at dilutions $\geq 1: 64$ were considered to be positive (FIGLIUOLO et al., 2004). Positive samples were subjected to four-fold dilutions, until the maximum titration reaction was reached. Positive and negative control serum samples were included in each test.

The ELISA test was performed in accordance with the methods described by Garcia et al. (2006). The reading was performed using a spectrophotometer with a $490 \mathrm{~nm}$ operating filter and a $600 \mathrm{~nm}$ differential filter. Positive and negative control serum samples were included on each plate and the corrected optical density (OD) was calculated as follows:

$$
\mathrm{OD}_{\text {corrected }}=\left[\frac{\left(\mathrm{OD}_{\text {sample }}-\mathrm{OD}_{\text {negative control }}\right)}{\left(\mathrm{OD}_{\text {positive control }}-\mathrm{OD}_{\text {negative control }}\right)}\right]
$$

Serum samples were considered positive when the OD was greater than [OD mean (negative control) $+2 \times$ negative control standard deviation (SD)].

Sensitivity, specificity, positive and negative predictive values, kappa index and efficacy were calculated on the basis of ELISA, using the IFA serum dilution 1:64 as reference. Association analyses were performed using the chi-square test and Fisher exact test $(\mathrm{p}<0.05)$, in order to correlate the serological results with the variables analyzed. The magnitude of the associations was determined according to the ratio of probability of occurrence (odds ratio) for a $95 \%$ confidence interval.

This study was approved by the Ethics Committee for Animal Experimentation (CETEA) of the Agroveterinary Science Center (CAV/UDESC), on May 30, 2008, under protocol no. 1.20.08.

\section{Results and Discussion}

Animals infected with T. gondii were found on all of the 13 farm properties assessed. Out of the 360 serum samples analyzed using IFA, 205 (56.94\%) were positive (Table 1). The titers observed were 64 (28.29\%), 256 (38.05\%), 1024 (22.44\%), 4096 (9.76\%) and $16384(1.46 \%)$. When subjected to ELISA, $153(42.50 \%)$ were reactive samples (Table 1 ).

The percentages of infected animals on the farm properties were in agreement with the results found by Figliuolo et al. (2004) and Ueno (2005), which were in similar surveys in the state of São Paulo and the Federal District, respectively. This high prevalence shows that $T$. gondii is widely distributed in sheep herds in the municipality of Lages, Santa Catarina.

The high percentage of $T$. gondii seropositive sheep found in this study may be related to environmental contamination with the parasite. Although vertical infection may occur, cats living in the same environment and the sheep's preference for grazing lower pastures, usually closer to the main buildings of the farm estate to which the cats normally have access, favor horizontal infection.

Tenter et al. (2000) reported that the incidence of antibodies in sheep populations in different countries ranged from 0 to $92 \%$. In Brazil, the rates of $T$. gondii infection in sheep ranged from $15.2 \%$ (ESCOPELLI, 2004) in the region of Porto Alegre, in Rio Grande do Sul, to 54.6\% (OGAWA et al., 2003) in the microregion of Londrina, in Paraná. The latter percentage is similar to what was obtained in the present work (56.94\%). In Guarapuava, Paraná, Romanelli et al. (2007) found a prevalence of $51.47 \%$. Lower values have been observed in Brazil and in other countries. Zonta et al. (1987) and Pappen (2008) found prevalences of $18.2 \%$ and $20.2 \%$, respectively, in different municipalities in Rio Grande do Sul. Gondim et al. (1999) found that the incidence of infection by $T$. gondii among sheep in Bahia was $18.75 \%$. Langoni et al. (2011) found that the prevalence was $18.6 \%$ in the eastern region of São Paulo. In the metropolitan and periurban regions of Curitiba, Paraná, Soccol et al. (2009) found that the incidence of infected animals was $25.75 \%$. 
Table 1. Toxoplasma gondii antibodies among sheep in the municipality of Lages, tested by enzime-linked immunosorbent assay (ELISA) and indirect immunofluorescence assay (IFA).

\begin{tabular}{|c|c|c|c|c|c|c|c|}
\hline \multirow[t]{3}{*}{ Variable } & \multirow[t]{3}{*}{ Category } & \multirow{2}{*}{\multicolumn{2}{|c|}{ Total number $(\mathrm{N})$ of sheep }} & \multicolumn{4}{|c|}{ Number of sheep with $T$. gondii antibodies } \\
\hline & & & & \multicolumn{2}{|c|}{ ELISA } & \multicolumn{2}{|c|}{ IFA } \\
\hline & & $\mathbf{n}$ & $\%$ & $\mathbf{n}$ & $\%^{1}$ & $\mathbf{n}$ & $\%^{1}$ \\
\hline \multirow{3}{*}{ Age } & $0-6$ months & 62 & 17.22 & 18 & 29.03 & 33 & 53.23 \\
\hline & $7-12$ months & 64 & 17.78 & 18 & 28.13 & 29 & 45.31 \\
\hline & $\geq 13$ months & 234 & 65.00 & 117 & 50.00 & 143 & 61.11 \\
\hline Sex & Males & 72 & 20.00 & 29 & 40.28 & 38 & 52.78 \\
\hline Breed & Mixed & 191 & 53.06 & 78 & 40.84 & 120 & 62.83 \\
\hline \multirow{2}{*}{ Contact with felines } & Yes & 275 & 76.39 & 127 & 46.18 & 155 & 56.36 \\
\hline & No & 85 & 23.61 & 26 & 30.59 & 50 & 58.82 \\
\hline \multirow[b]{2}{*}{ Diet } & Natural pasture & 110 & 30.56 & 58 & 52.73 & 70 & 63.64 \\
\hline & Mixed & 188 & 52.22 & 77 & 40.96 & 102 & 54.26 \\
\hline \multirow{3}{*}{ Breeding problems } & Miscarriage & 4 & 1.11 & 4 & 100.00 & 4 & 100.00 \\
\hline & Stillborn & 1 & 0.28 & 0 & 0.00 & 1 & 100.00 \\
\hline & None & 355 & 98.61 & 149 & 41.97 & 200 & 56.34 \\
\hline \multirow{6}{*}{ Animal category } & Lambs & 62 & & 19 & 30.65 & 33 & 53.23 \\
\hline & Pregnant ewes & 80 & & 46 & 57.50 & 51 & 63.75 \\
\hline & Non-pregnant ewes & 84 & & 24 & 28.57 & 44 & 52.38 \\
\hline & Lactating ewes & 90 & & 44 & 48.89 & 56 & 62.22 \\
\hline & Uncastrated males & 17 & & 10 & 58.82 & 7 & 41.18 \\
\hline & Castrated males & 27 & & 10 & 37.04 & 14 & 51.85 \\
\hline Total & & 360 & & 153 & 42.50 & 205 & 56.94 \\
\hline
\end{tabular}

${ }^{1}$ Relationship between the number of infected animal per category, and total number of animals within each category; ${ }^{2}$ Hampshire Down and Texel.

It was found, regarding age, that the population sampled consisted mainly of animals aged $\geq 13$ months (65\%). Older age is considered to be a risk factor for toxoplasmosis because adult animals have a higher likelihood of coming into contact with $T$. gondii oocysts in the environment. However, this was not observed in the results obtained from IFA, since there was no statistically significant difference $(\mathrm{p}>0.05)$ in the seroprevalence to $T$. gondii in relation to the sheep's age (Table 2). The percentages were found to be higher among older animals by several authors: Van der Puije et al. (2000) in Ghana; Figliuolo et al. (2004) in São Paulo; Romanelli et al. (2007) in the state of Paraná; Carneiro et al. (2009) in Minas Gerais; and Tembue et al. (2009) in the arid region of the state of Pernambuco.

There was no statistically significant difference $(p>0.05)$ in the incidence of seropositivity in relation to the sex of the animals (Table 2). These results are in agreement with the majority of studies on the prevalence of $T$. gondii in sheep (ESCOPELLI, 2004; CARNEIRO et al., 2009). Discrepant results were obtained by Silva et al. (2003), Ueno (2005) and Ragozo (2007) in Pernambuco, Federal District and São Paulo, respectively, with a higher seropositivity rate among males. Van der Puije et al. (2000) conducted experiments on sheep in Ghana, and pointed out that female sex was a risk factor for toxoplasmosis because of hormonal, physical and management differences. According to Ueno (2005),
Table 2. Univariate analysis on risk factors associated with infection by Toxoplasma gondii, assessed through the immunofluorescence assay ( $\geq 1: 64)$ among sheep in the municipality of Lages, Santa Catarina, in 2009 .

\begin{tabular}{lccc}
\hline \multicolumn{1}{c}{ Variables } & $\mathbf{P}$ & OR & $\mathbf{9 5 \%} \mathbf{C I}$ \\
\hline Age & 0.14 & - & - \\
Sex & 0.68 & 0.86 & $0.50-1.51$ \\
Breed & 0.02 & 1.66 & $1.07-2.60$ \\
Contact with felines & 0.78 & 0.90 & $0.53-1.52$ \\
Diet & 0.23 & - & - \\
Water source & 0.58 & 0.80 & $0.41-1.57$ \\
Breeding problems & 0.13 & 0 & $0-1.43$ \\
Animal category & 0.14 & - & - \\
\hline
\end{tabular}

$\mathrm{P}=$ Probability; $\mathrm{OR}=$ Odds ratio; $95 \% \mathrm{CI}=95 \%$ confidence interval.

this variable does not influence the results, given the divergence in the results, especially because of the lack of consistent biological explanations and because this variable is a random factor. In the present study, crossbred animals showed statistical differences in the seroprevalence of anti-T. gondii $(\mathrm{p}<0.05$, Table 2$)$. These results are in agreement with those found by Silva et al. (2003), who found higher rates of infection in crossbred animals. According to those authors, this finding could be explained in terms of the 
unsatisfactory hygiene conditions during herd health management among crossbred animals, thus disagreeing with the findings of Van der Puije et al. (2000) and Carneiro et al. (2009).

The variable of contact with felines related to the presence of domestic cats on the farm property. Stray cats and wild felines were not categorized within this variable, because they have habits and habitat characteristics that differ from those of domesticated animals, and do not have a close relationship with sheep. In this study, no statistically significant difference in seropositivity ( $p>0.05$ ) was found in relation to the presence and/or contact of sheep with felines (Table 2), which is in agreement with the data obtained by Soares et al. (2009). These results disagree with those found by Romanelli et al. (2007) in the state of Paraná and by Pappen (2008) in the southern region of Rio Grande do Sul. These authors stated that access by cats to the feed storage barn, presence of young cats and raising sheeps near to the farmhouse were factors associated with a greater chance of ingesting oocysts. According to Hill and Dubey (2002), there is a relationship between the presence of definitive hosts and the epidemiology of $T$. gondii infections, since the transmission of $T$. gondii to sheep is mainly attributed to oocysts shed by infected cats over pasture and water.

There was no statistically significant difference in seropositivity ( $p>0.05)$ in relation to the type of diet among the sheep (Table 2), although almost half of the animals received a mixed diet. In Minas Gerais, Carneiro et al. (2009) also observed that the diet of animals was not a factor that contributed to the risk of toxoplasmosis in sheep.

The IFA results showed that there was no statistically significant correlation between the water source and $T$. gondii infections ( $p>0.05$, Table 2). However, Romanelli et al. (2007) and Vesco et al. (2007) found a correlation between $T$. gondii seropositivity and surface water sources, as these were more likely to be contaminated with $T$. gondii oocysts.

There was no statistically significant difference in seropositivity $(p>0.05)$ in relation to reproductive problems (abortion and stillbirth) among the sheep according to IFA, although all the sheep that aborted were seropositive for $T$. gondii. This result was in agreement with what was found by Ogawa et al. (2003) in Paraná and by Carneiro et al. (2009) in Minas Gerais.

The ELISA and IFA serological tests are considered to be suitable for epidemiological studies on toxoplasmosis in sheep because they are practical techniques with high sensitivity and specificity (SAWADOGO et al., 2005). In the present study, the sensitivity $(61 \%)$ and specificity (82\%) of ELISA, at dilutions $\geq 1: 64$ (Table 3), were lower than those reported by Van der Puije et al. (2000), who used IFA and ELISA in seroprevalence studies conducted in Ghana, Africa. In Cairo, Egypt, Shaapan et al. (2008) found T. gondii antibody prevalences of $37 \%$ using IFA, $41.7 \%$ using ELISA, $43.7 \%$ using the modified agglutination test (MAT) and $34 \%$ using the dye test (DT). When data from the first three serological tests were compared with the DT, which was used as the reference for toxoplasmosis, MAT was the test that showed the highest sensitivity (96\%), followed by ELISA (90.1\%) and IFA, which showed low sensitivity $(80.4 \%)$. On the other hand, IFA showed the highest specificity $(91.4 \%)$, followed by MAT (88.9\%) and ELISA (85.9\%).
Table 3. Sensitivity (SE), specificity (SP), positive predictive value (PPV), negative predictive value (NPV), kappa and efficacy of the immunosorbent assay (ELISA), using the immunofluorescence assay (IFA) as reference ( $\geq 64)$, among 360 sheep serum samples from the municipality of Lages, Santa Catarina, Brazil.

\begin{tabular}{cccc}
\hline ELISA Result & \multicolumn{2}{c}{ IFA Result } & Total \\
\cline { 2 - 3 } & Positive & Negative & \\
\hline Positive & 125 & 28 & 153 \\
Negative & 80 & 127 & 207 \\
Total & 205 & 155 & 360 \\
\hline SE $=61.0 \% ;$ SP $=81.9 \% ;$ PPV $=81.7 \%$ NPV $=61.3 \%$; Kappa index $=0.41 ;$ \\
Efficacy $=70 \%$.
\end{tabular}

In the present study, ELISA conducted on sheep serum samples was found to be more specific than sensitive. The moderate agreement $(\mathrm{kappa}=0.41)$ between ELISA and IFA (1:64) allows to consider that ELISA is an alternative technique for diagnosing T. gondii in sheep. Pereira-Bueno et al. (2004) found perfect agreement between IFA and ELISA (kappa $=1.00$ ) in a study conducted on sheep in Spain. However, in a study on sheep in Rio Grande do Sul, using indirect hemagglutination (HAI) and IFA techniques, Escopelli (2004) found a kappa value of 0.51, thus showing moderate agreement between the two techniques. Carneiro et al. (2009) compared ELISA and IFA (1:64) in Minas Gerais, and observed that the kappa value showed substantial agreement (0.68).

\section{Conclusions}

- Infection by $T$. gondii is widespread in sheep herds in the municipality of Lages, Santa Catarina, and seropositive animals were detected on $100 \%$ of the farm properties analyzed;

- Sheep in the municipality of Lages, Santa Catarina, showed high prevalence of antibodies to T. gondii: $56.94 \%$ according to IFA and $42.50 \%$ according to ELISA;

- Breed was associated with the risk of acquiring T. gondii infection; and

- The kappa agreement level between IFA and ELISA was considered to be moderate, and therefore ELISA can be used as an alternative technique for diagnosing toxoplasmosis in epidemiological studies among sheep.

\section{References}

Brasil. Fundação Nacional de Saúde. Doenças Parasitárias. Rio de Janeiro: Ministério da Saúde; 2002. Manual de Toxoplasmose. Available from: http://www.funasa.gov.br/pub/boletim_eletronico.

Camargo ME. Improvided technique of indirect immunofluorescence for serological diagnosis of toxoplasmosis. Rev Inst Med Trop São Paulo 1964; 6(3): 117-118.

Carneiro ACAV, Carneiro M, Gouveia AMG, Vilas-Boas LS, Vitor RWA. Seroprevalence and risk factors of sheep toxoplasmosis in Minas Gerais, Brazil. Revue Méd Vét 2009; 160(11): 527-531. 
Centers for Disease Control and Prevention - CDC. Epi Info. [online]. 1996. [cited 2008 Jun. 10]. Available from: http://www.cdc. gov/epiinfo/ei1996.htm.

Companhia Integrada de Desenvolvimento Agrícola de Santa Catarina - CIDASC, Instituto Catarinense de Sanidade Agropecuária - ICASA. 2008. Available from: http://www.cidasc. sc.gov.br.

Dubey JP, Thulliez P. Persistence of tissue cysts in edible tissues of cattle fed Toxoplasma gondii oocysts. Am J Vet Res 1993; 54(2): 270-273. PMid:8430937.

Escopelli KS. Avaliação sorológica de anticorpos da classe IgG para Toxoplasma gondii em soros de ovinos da regiāo da Grande Porto Alegre/RS, através das técnicas de hemaglutinação indireta (HAI) e imunofluorescência indireta (IFI) [Dissertação]. Porto Alegre: Universidade Federal do Rio Grande do Sul; 2004.

Figliuolo LPC, Kasai N, Ragozo AMA, De Paula VSO, Dias RA, Souza SLP, et al. Prevalence of anti-Toxoplasma gondii and antiNeospora caninum antibodies in ovine from São Paulo State, Brazil. Vet Parasitol 2004; 123(3-4): 161-166. http://dx.doi.org/10.1016/j. vetpar.2004.06.006

Garcia JL, Navarro IT, Vidotto O, Gennari SM, Machado RZ, Da Luz Pereira AB, et al. Toxoplasma gondii: Comparison of a rhoptry-ELISA with IFAT and MAT for antibody detection in sera of experimentally infected pigs. Exp Parasitol 2006; 113(2): 100-105. PMid:16458299.

Gondim LFP, Barbosa Junior HV, Ribeiro Filho CHA, Saeki H. Serological survey of antibodies to Toxoplasma gondii in goats, sheep, cattle and water buffaloes in Bahia State, Brazil. Vet Parasitol 1999; 82(4): 273-276. http:// dx.doi.org/10.1016/S0304-4017(99)00033-3

Hill D, Dubey JP. Toxoplasma gondii: transmission, diagnosis and prevention. Clin Microbiol Infect 2002; 8(10): 634-640. PMid:12390281.

Instituto Brasileiro de Geografia e Estatística - IBGE. 2009.[cited 2011 Out. 15]. Available from: http://www.ibge.gov.br.

Langoni H, Greca Junior H, Guimarães FF, Ullmann LS, Gaio FC, Uehara RS, et al. Serological profile of Toxoplasma gondii and Neospora caninum infection in commercial sheep from São Paulo State, Brazil. Vet Parasitol 2011; 177(1-2): 50-54. http://dx.doi.org/10.1016/j. vetpar.2010.11.024

Ogawa L, Navarro IT, Freire RL, Oliveira RC. Occurrence of antibodies to Toxoplasma gondii in sheep from the Londrina Region of the Paraná State, Brazil. Semina Cienc Agrar 2003: 24(1): 57-62.

Pappen FG. Prevalência de anticorpos para Toxoplasma gondii (Nicolle e Manceaux, 1909) em ovinos da regiáo sul do Estado do Rio Grande do Sul [Dissertação]. Pelotas: Universidade Federal de Pelotas; 2008.

Paré J, Hietala SK, Thurmond. Interpretation of an indirect fluorescent antibody test for diagnosis of Neospora sp infection in cattle. J Vet Diagn Invest 1995; 7(2): 273-275. PMid:7619917.

Pereira-Bueno J, Quintanilla-Gozalo A, Pérez-Pérez V, Alvarez-García G, Collantes-Fernández E, Ortega-Mora LM. Evaluation of ovine abortion associated with Toxoplasma gondii in Spain by different diagnostic techniques. Vet Parasitol 2004; 121(1-2): 33-43. http://dx.doi. org/10.1016/j.vetpar.2004.02.004

Ragozo AMA. Isolamento e caracterização biológica e genotípica de Toxoplasma gondii de ovinos e caprinos [Tese]. São Paulo: Universidade de São Paulo; 2007.

Romanelli PR, Freire RL, Vidotto O, Marana ER, Ogawa L, De Paula VS, et al. Prevalence of Neospora caninum and Toxoplasma gondii in sheep and dogs from Guarapuava farms, Paraná State, Brazil. Res Vet Sci 2007; 82(2): 202-207. http://dx.doi.org/10.1016/j.rvsc.2006.04.001

Sawadogo P, Hafid J, Bellete B, Sung RT, Chakdi M, Flori P, et al. Seroprevalence of Toxoplasma gondii in sheep from Marrakech, Marocco. Vet Parasitol 2005; 130(1-2): 89-92. http://dx.doi.org/10.1016/j. vetpar.2005.03.025

Shaapan RM, El-Nawawi FA, Tawfik MA. Sensitivity and specificity of various serological tests for the detection of Toxoplasma gondii infection in naturally infected sheep. Vet Parasitol 2008; 153(3-4): 359-362. http:// dx.doi.org/10.1016/j.vetpar.2008.02.016

Silva AV, Cunha ELP, Meireles LR, Gottschalk S, Mota RA, Langoni H. Toxoplasmose em ovinos e caprinos: estudo soroepidemiológico em duas regiôes no Estado de Pernambuco, Brasil. Ciênc Rural 2003; 33) (1): 115-119.

Soares HS, Ahid SMM, Bezerra ACDS, Pena HFJ, Dias RA, Gennari SM. Prevalence of anti-Toxoplasma gondii and anti-Neospora caninum antibodies in sheep from Mossoró, Rio Grande do Norte, Brazil. Vet Parasitol 2009; 160(3-4): 211-214. http://dx.doi.org/10.1016/j. vetpar.2008.10.102

Soccol VT, Castro EA, Gazda TL, Garcia G, Richartz RRTB, Dittrich RL. Ocorrência de anticorpos anti- Toxoplasma gondii em ovinos das áreas urbanas e periurbanas de Curitiba, Paraná. Rev Bras Parasitol Vet 2009; 18(S1): 69-70. http://dx.doi.org/10.4322/rbpv.018e1013

Tembue AA, Alves LC, Costa AJ, Faustino MAG, Sousa TR, Albuquerque $\mathrm{AR}$, et al. Prevalence of IgG antibodies anti-Toxoplasma gondii in goat and sheep from dry region of Pernambuco State, Brazil. Rev Ibero-latinoam Parasitol 2009; 68(1): 82-85.

Tenter AM, Heckeroth AR, Weiss LM. Toxoplasma gondii: from animals to humans. Int J Parasitol 2000; 30(12-13): 1217-1258. PMid:11113252.

Ueno TEH. Prevalência das infecçöes por Toxoplasma gondii e Neospora caninum em matrizes e reprodutores ovinos de rebanhos comerciais do Distrito Federal, Brasil [Dissertação]. São Paulo: Universidade de São Paulo; 2005.

Van der Puije WN, Bosompem KM, Canacoo EA, Wastling JM, Akanmori BD. The prevalence of anti-Toxoplasma gondii antibodies in Ghanaian sheep and goats. Acta Trop 2000; 76(1): 21-26. PMid:10913761.

Vesco G, Buffolano W, La Chiusa S, Mancuso G, Caracappa S, Chianca A, et al. Toxoplasma gondii infections in sheep in Sicily, southern Italy. Vet Parasitol 2007; 146(1-2): 3-8. http://dx.doi.org/10.1016/j. vetpar.2007.02.019

Zonta JC, Araújo FAP, Stobbe NS, Chaplin EL, Silva NRS. Prevalência de anticorpos toxoplásmicos em ovinos de Marau e de Uruguaiana, RS. Arq Fac Vet UFRGS 1987; 15: 59-61. 